Recent Advances in Communication, Electronics \& Electrical Engineering

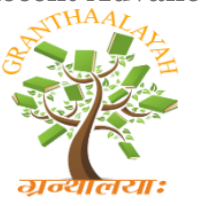

INTERNATIONAL JOURNAL OF RESEARCH -

GRANTHAALAYAH

A knowledge Repository

RACEEE - 17

\title{
MODELING SIMULATION AND PERFORMANCE STUDY OF GRID- CONNECTED PHOTOVOLTAIC ENERGY SYSTEM
}

\author{
Nagendra $\mathrm{K}^{* 1}$, Karthik $\mathrm{J}^{2}$, Keerthi Rao $\mathrm{C}^{3}$, Kumar Raja Pemmadi ${ }^{4}$ \\ $* 1,2,3,4$ Department of Electrical and Electronics Engineering, School of Engineering and \\ Technology, Jain University, Karnataka- 562112, India
}

DOI: https://doi.org/10.29121/granthaalayah.v5.i4RACEEE.2017.3320

\begin{abstract}
This paper presents Modeling Simulation of grid connected Photovoltaic Energy System and performance study using MATLAB/Simulink. The Photovoltaic energy system is considered in three main parts PV Model, Power conditioning System and Grid interface. The Photovoltaic Model is inter-connected with grid through full scale power electronic devices. The simulation is conducted on the PV energy system at normal temperature and at constant load by using MATLAB.
\end{abstract}

Keywords: Photovoltaic System Model; Power Converters; PQ Control; LC Filter and MATLAB/Simulink.

Cite This Article: Nagendra K, Karthik J, Keerthi Rao C, and Kumar Raja Pemmadi. (2017). "MODELING SIMULATION AND PERFORMANCE STUDY OF GRID-CONNECTED PHOTOVOLTAIC ENERGY SYSTEM." International Journal of Research Granthaalayah, 5(4) RACEEE, 36-41. 10.29121/granthaalayah.v5.i4RACEEE.2017.3320.

\section{Introduction}

In recent years, the renewable energy sources have been more attractive and available, due to severe shortage of conventional energy sources and expensive. PV energy System uses renewable energy source (sunlight) has its input and converts its input into electrical energy (Output).

The Photovoltaic model is connected to grid and local loads through power conditioning system, which controls power electronic devices to get three phases AC Power. The power conditioning system consists of DC/DC Boost Converter, Voltage Source Inverter (VSI), PQ control theory and Pl controller tuning, PWM generator. The Photovoltaic energy system is simulated and studied under normal conditions using MATLAB/ Simulink. 
Recent Advances in Communication, Electronics \& Electrical Engineering

\section{Modeling Of Photovoltaic Energy Conversion System}

\section{PV Model}

PV MODEL is a collection array of Photovoltaic cells, Photovoltaic cells converts Irradiation into electrical energy. Photovoltaic cells are made up of Semiconductor a material which works on the principle of photoelectric effect. And by using photoelectric effect the current and voltage is produced, in term power is produced.

\section{Types of PV Model}

There are two types of photovoltaic energy systems:

- Grid connected system.

- Stand-alone system.

\section{Grid Connected}

PV system is made to power the local load and the grid. Inverter, power conditioning unit are the main component and it controls the flow of power in local load, grid, and also in distribution network with a standard voltage and power.

\section{Stand Alone System}

Stand alone type is designed to feed local loads and these are operated independently without grid interface.

\section{DC/DC Boost Converter}

The boost converter is connected in between RES and DC link. The DC/DC boost converter is used to boost the voltage and get regulated output. To reduce ripple the DC link capacitor is connected between PV system and the boost converter.

\section{PI Controller}

Using PI Controller the DC link error signal is generated by comparing actual DC output voltage with reference voltage. The error signal is fed to PWM generator to regulate DC/DC Boost Converter output. The Regulated DC output voltage is feed to VSI through the DC link.

The below figure shows the block diagram of grid-connected Photovoltaic energy system. It consists of Photovoltaic energy conversion system inter-connected with grid. Photovoltaic energy conversion system output is connected to DC/DCboost converter to control and to get the regulated DC Output voltage. Then it is connected to voltage source inverter (VSI) through DC link. 
Recent Advances in Communication, Electronics \& Electrical Engineering

\section{Block Diagram of Grid Connected Photovoltaic Energy System}

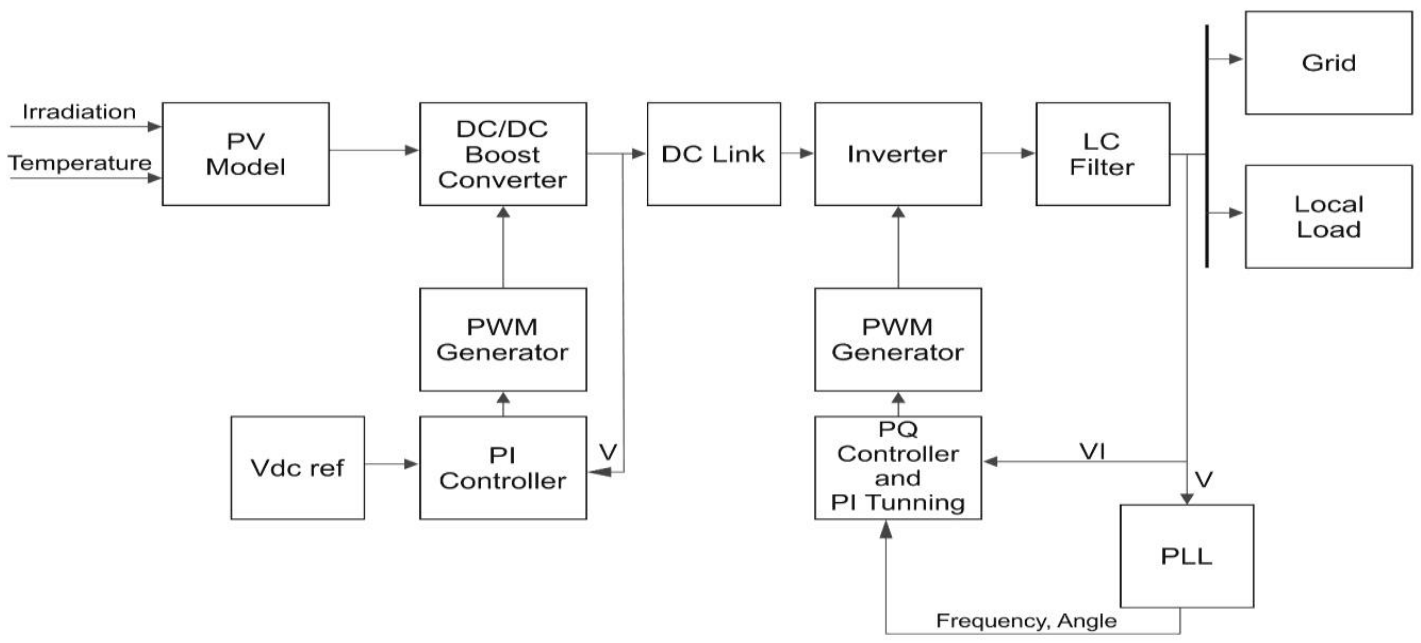

Figure 1:

\section{Three Phase Inverter}

Basically, the operation of inverter is reverse of converter. The DC output we get from boost converter is converted into AC with help of VSI. VSI consists of six switches PWM with an output of 1200phase shift. A six-step bridge inverter consists of six thyristors. Then it is gated at regular interval of 600 for a complete 3600 so that we get 3 phase ac voltage. Replacing thyristors with IGBTs have been the present trend.

The Inverter is interconnected between DC/DC boost converter and the LC filter circuit, the regulated DC output Voltage of DC/DC boost converter is feed to Inverter. VSI converts the DC voltage into 3 phase AC voltage.

The PWM switching pulses are generated based on error signals. The Output of the LC filter is selected as the reference and the modulating signal is generated by the block. And the generated switching pulses are used to control the six switches present in the inverter. The PLL (Phase Locked Loop) is connected to output reference of LC filter, to measure the grid voltage phase angle, which is used to synchronize the inverter with grid. PQ controller is used to control active and reactive power. By using PI controller the PQ controller is tuned based on error signals to get regulated $\mathrm{AC}$ output.

\section{Design LC Filter}

The waveform quality is improved by connecting an LC filter in series with the Inverter and the grid.

According to thumb rule of control theory the frequencies of LC filter configuration have at least multiples of 10 between fundamental, resonance and switching frequencies to decouple the effects. The resonance frequency is given by, 
Recent Advances in Communication, Electronics \& Electrical Engineering

Where,

$$
\omega_{\mathrm{r}}=\frac{1}{\sqrt{\mathrm{L}_{\mathrm{f}} * \mathrm{C}_{\mathrm{f}}}}
$$

$$
\begin{aligned}
& \omega \mathrm{r}=\text { Resonance frequency } \\
& \mathrm{Lf}=\text { Filter inductance. } \\
& \mathrm{Cf}=\text { Filter capacitance. }
\end{aligned}
$$

\section{Results}

Under steady operation all parameters are kept constant. Solar irradiation $1000 \mathrm{~W} / \mathrm{m} 2$, temperature $250 \mathrm{C}$, and load parameters active power $100 \mathrm{~kW}$, reactive power $60 \mathrm{kVAR}$ are given to simulated model with $415 \mathrm{~V}, 50 \mathrm{~Hz}$ as grid parameter.

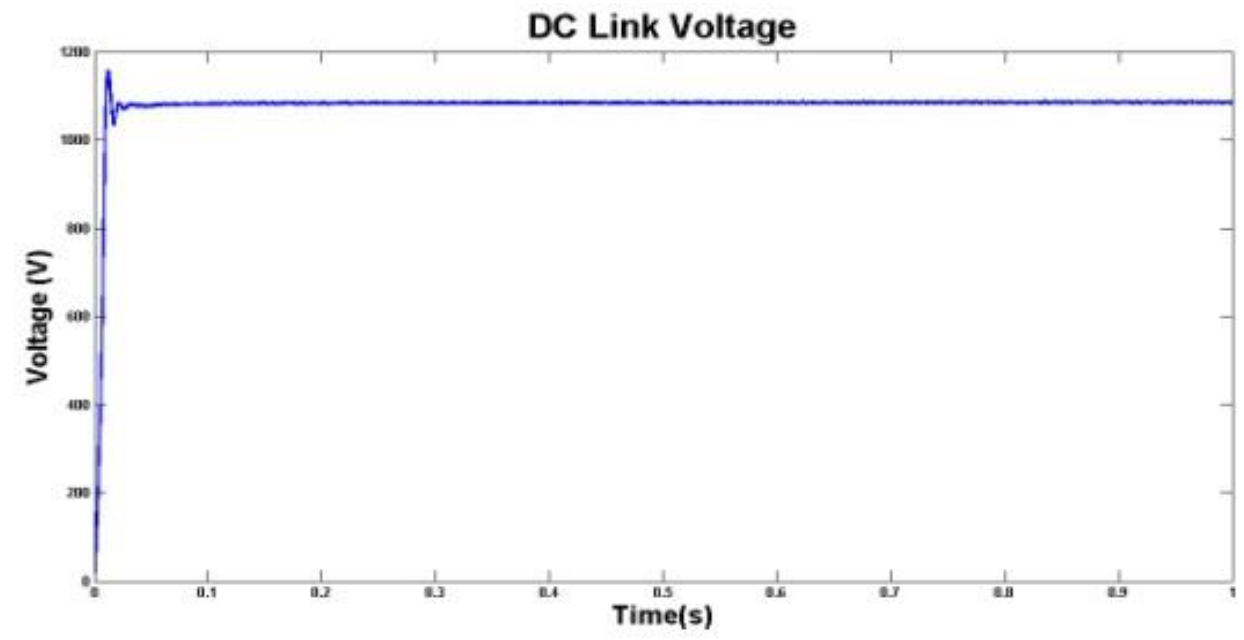

Figure 2: DC Link Voltage
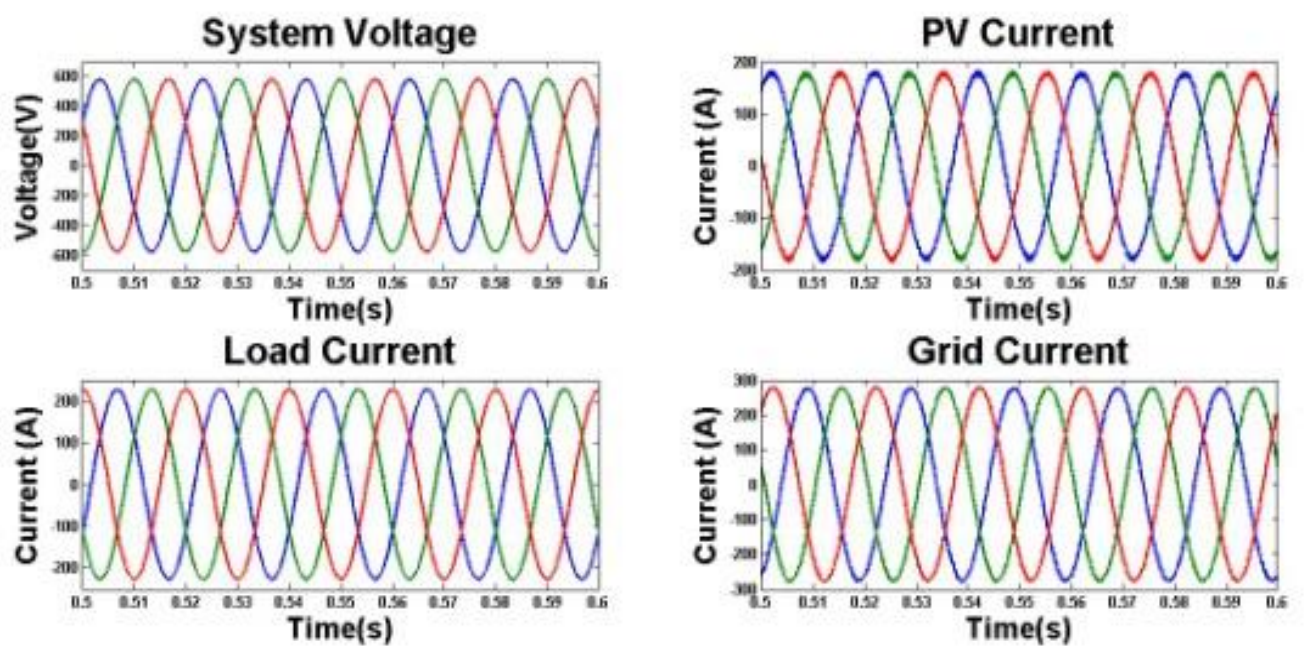

Figure 3: Voltage \& Currents at AC Bus 
Recent Advances in Communication, Electronics \& Electrical Engineering
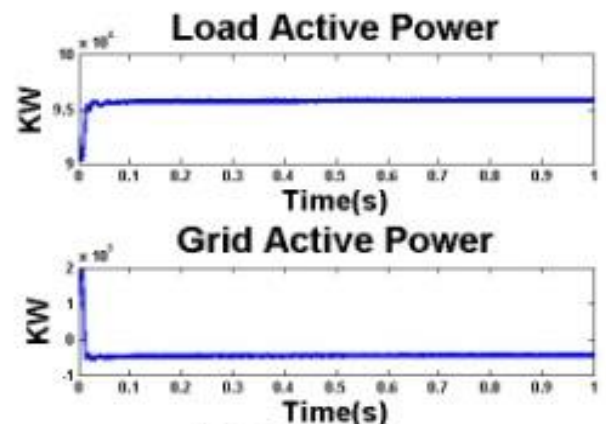

PV Active Power

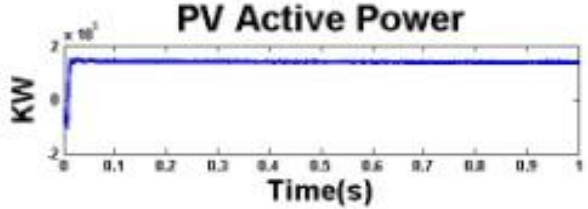

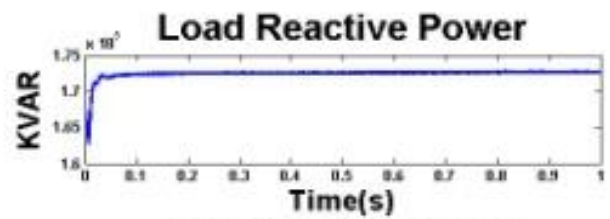
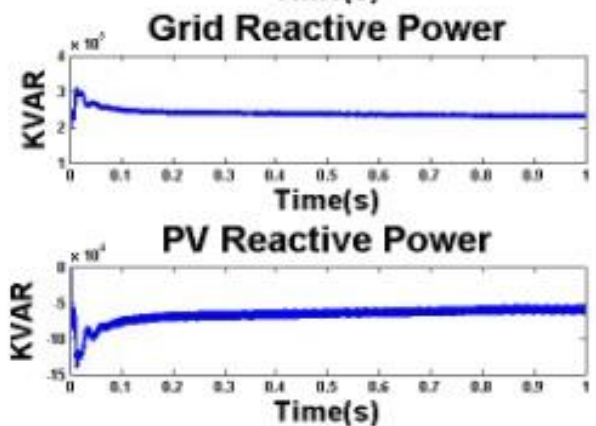

Figure 4: Active \& Reactive Powers

In Fig 2 Constant DC link voltage is obtained during simulation, in Fig 3 Voltage \& currents are constant, in Fig 4 Active \& reactive powers are constant.

\section{Conclusions}

Here the modeling of grid connected PV system has made using MATLAB/Simulink.

The PQ control is used to control VSI. This control is giving good response with grid interface.

PI controller tuning can be done by adaptive fuzzy or artificial neural network (ANN) to get good performance.

\section{References}

[1] Akshay B. Zade, Asha Gaikwad, Ku. Prachi M. Jeevane, Ganesh Lohote.:Hybrid Solar and Wind Power Generation with Grid Interconnection System for Improving Power Quality.In: International Conference on Power Electronics, Intelligent Control and Energy Systems IEEE, 2016.

[2] SajibChakraborty, S M Salim Reza, WahidulHasan.:Design and Analysis of Hybrid Solar-Wind Energy System Using CUK \& SEPIC Converters for Grid Connected Inverter Application.In: IEEE PEDS, 2015.

[3] Md. Nurunnabi, N. K. Roy.:Grid Connected Hybrid Power System Design Using HOMER.In: 3rd International Conference on Advances in Electrical Engineering", December, IEEE, 2015.

[4] B. M Hasaneen and Adel A. ElbasetMohammed.:Design and Simulation of DC/DC Boost Converter.In: IEEE Power System Conference, 2008.

[5] MubasharYaqoobZargar, Mairaj-ud-Din Mufti, Shameem Ahmed Lone.: Modelling and Control of Wind Solar Hybrid System Using Energy Storage System.In: International Conference on Computing, Communication and Automation, IEEE, 2016.

[6] Vechiu, A. Llaria, O. Curea and H. Camblong.:Control of Power Converters for Microgrids.In: EVER'09, Monaco, 26-29 March 2009. 
Recent Advances in Communication, Electronics \& Electrical Engineering

[7] Sunil Patel, NayanaPrajapati.:Grid Connected Solar and Wind Hybrid System.In: International Journal for Innovative Research in Science \& Technology, May 2016.

[8] Sara GhaemSigarchiana, AndersMalmquista,TorstenFranssona.: Modeling and controlstrategy of a hybrid PV/Wind/Engine/Battery system toprovide electricity and drinkable water for remoteapplication. In: ISES Solar World Congress, 2013, Energy Procedia 57 (2014) 1401 1410.

[9] SeddikBacha, Damien Picault, Bruno Burger, Ion

[10] Etxeberria-Otadui, Joao Martins.: Photovoltaics in Microgrids: An Overview of Grid Integration and Energy Management Aspects. In: IEEE Industrial Electronics Magazine 03/2015; 9(1):33-46.

*Corresponding author.

E-mail address: kbnagendra@gamil.com 